\title{
Penerimaan Pengguna Terhadap Sistem Informasi Manajemen BAZNAS dan Kesesuaian Dengan PSAK Nomor 109 (Studi Kasus pada Badan Amil Zakat Nasional Kabupaten Jember)
}

\author{
(Admission of BAZNAS Management Information System's User and Compliance with \\ PSAK Number 109 (A Case Study at Badan Amil Zakat Nasional Jember))
}

\author{
Cici Wijayanti', Ahmad Roziq, Ririn Irmadariyani \\ Jurusan Akuntansi, Fakultas Ekonomi dan Bisnis, Universitas Jember (UNEJ) \\ Jln. Kalimantan 37, Jember 68121 \\ E-mail:wijayantic@yahoo.com
}

\begin{abstract}
Abstrak
Penelitian ini bertujuan untuk menganalisis penerimaan pengguna terhadap penerapan Sistem Informasi Manajemen Baznas (SIMBA) berdasarkan teori Technology Acceptance Model (TAM) serta menilai terkait pelaporan keuangan dalam SIMBA menghasilkan informasi yang akurat dan kesesuaian dengan PSAK Nomor 109. Objek penelitian pada penelitian ini adalah Badan Amil Zakat Nasional (BAZNAS) Kabupaten Jember. Metodologi yang digunakan adalah penelitian kualitatif dengan pendekatan studi kasus. Analisis penerimaan pengguna terhadap SIMBA disesuaikan dengan faktor-faktor yang dibentuk oleh Davis dan kesesuaian akuntansi zakat, infak atau sedekah dalam SIMBA dinilai dari aspek pengakuan, penyajian, dan pengungkapan. Berdasarkan hasil penelitian bahwa pengguna SIMBA di BAZNAS Kabupaten Jember mencerminkan faktorfaktor yang dibentuk oleh Davis dengan menduga terdapat dua faktor eksternal lainnya, yaitu pengetahuan dan keterampilan. SIMBA dari aspek pengakuan, penyajian, dan pengakuan telah sesuai dengan PSAK 109, kecuali dari pengungkapan tidak dapat menambah paragraf baru.
\end{abstract}

Kata Kunci: Akuntansi Zakat, Infak, atau Sedekah, BAZNAS, PSAK 109, SIMBA, TAM.

\begin{abstract}
This research aimed to analysis the admission of Sistem Informasi Manajemen BAZNAS (SIMBA)'s user based on Technology Acceptance Model (TAM) theory and assess the financial reporting in SIMBA generate accurate information and compliance with PSAK No. 109. The object of research in this research is Badan Amil Zakat Nasional (BAZNAS) Jember. The research methodology was qualitative research case study approach. The analysis of the acceptance SIMBA's user adjusted by factors developed by Davis and the suitability of accounting for zakat, infaq, or alms was assessed from recognition, presentation, and disclosure aspects. The result of this research was the SIMBA's user in BAZNAS Jember reflect the factors developed by Davis by assuming there are two other external factors, i.e. knowledge and skill. SIMBA from the aspect of recognition, presentation, and disclosure was accordance with PSAK 109, except form disclosure can not add a new paragraph.
\end{abstract}

Keywords: Accounting for Zakat, Infaq, and Alms, BAZNAS, PSAK 109, SIMBA, TAM.

\section{Pendahuluan}

Perkembangan lembaga keuangan shariah pada tingkat nasional maupun internasional telah memberikan bukti bahwa sistem ekonomi shariah mampu menyesuaikan dengan perekonomian konvensional di Indonesia. Salah satu lembaga keuangan shariah yang mendukung perkembangan sistem ekonomi Islam dan menjadi perhatian masyarakat luas yaitu BAZ. Dalam Islam telah dijelaskan terkait perintah untuk menginvestasikan atau membelanjakan pendapatan yang diperoleh untuk hal yang halal dan bermanfaat. Sebuah hadits Rasulullah yang diriwayatkan oleh Anas Ibn Malik menyebutkan bahwa: "Tidak akan habis harta seseorang hanya karena dia membayar zakat."

Di Indonesia, diatur dalam UU No 23 Tahun 2011 tentang Pengelolaan Zakat, dimana ada dua Organisasi Pengelolaan Zakat (OPZ), yaitu Badan Amil Zakat (BAZ) dan Lembaga Amil Zakat (LAZ). Pemerintah mendirikan OPZ tidak lepas dari akuntabilitas atau pertanggungjawabannya kepada publik. Akuntabilitas memerlukan standar yang mengatur pencatatan, pelaporan, dan pengalokasian dana zakat, infak dan shadaqah tersebut. Standard yang digunakan untuk pengelolaan dana zakat yaitu PSAK No 109. Pada awal 2012, pemerintah membentuk sebuah sistem manajemen dimana dapat memberikan informasi yang dibutuhkan oleh muzakki maupun mustahiq.

SIMBA berisikan informasi dari BAZNAS setiap provinsi atau kabupaten selama satu periode, baik daftar muzakki maupun laporan keuangannya. SIMBA memiliki dua sistem, yaitu Sistem Informasi Operasional (SIO) dan Sistem Informasi Pelaporan (SIP). SIO digunakan untuk operasi sehari-hari dengan pendekatan kas masuk dan kas keluar. Kas masuk dapat di-input pada data muzakki dan transaksi penghimpunan zakat, infaq dan shadaqah serta kas keluar dapat di-input pada data mustahiq dan penyaluran zakat, infaq, dan shadaqah. Data-data tersebut maupun data keuangan lainnya, termasuk transaksi keuangan akan di-input dan menghasilkan laporan, seperti profil muzakki, jumlah penghimpunan dana zakat, infaq, dan shadaqah, profil asnaf, dan jenis program penyaluran. Laporan keuangan standar

\footnotetext{
* Corresponding author
} 
mengacu pada PSAK No 109. (Permudah Transaksi, BAZNAS Luncurkan Sistem Manajemen Berbasis Teknologi | gomuslim, n.d.).

SIMBA merupakan sistem informasi manajemen berbasis teknoologi yang diharapkan meringankan beban kinerja dari pengguna. Tidak semua pengguna dapat menerima penggunaan teknologi tersebut.

BAZNAS Kabupaten Jember baru didirikan pada bulan Agustus 2017. BAZNAS tersebut telah menerapkan SIMBA dalam sistemnya. Lembaga ini masih menerapkan sistem tersebut sekitar satu tahun yang lalu atau pada tahun 2018. Lembaga yang dikelompokkan baru beroperasi dengan menerapkan sistem ini, masih memungkinkan ditemukan hambatan dalam kinerjanya, terutama dari pengguna itu sendiri. Hambatan tersebut bisa ditemukan melalui internal maupun eksternal. Dari penjabaran tersebut, peneliti tertarik untuk menganalisis persepsi pengguna di Baznas Jember terhadap SIMBA sebagai sistem yang digunakan untuk pencatatan operasional selama satu periode serta menilai kesesuaian laporan keuangan yang dihasilkan oleh SIMBA dengan PSAK 109

Di Indonesia teori akuntansi Shariah dikenal sekitar tahun 1997, dimana teori ini meleburkan dinding pembatas antara akuntansi dan ilmu agama (Triyuwono, 2001). Shariah enterprise theory memberikan bentuk pertanggungjawabannya kepada Allah (vertikal) yang kemudian dijabarkan pertanggungjawabannya secara horizontal, yaitu kepada umat manusia dan lingkungan alam. Teori ini menyajikan value-added statement (laporan nilai tambah). Value-added statement sama seperti laporan laba rugi pada umumnya, namun laporan ini lebih menekankan pada distribusi nilai tambah yang diciptakan kepada mereka yang berhak menerimanya (Triyuwono, 2001).

Technology acceptance model merupakan salah satu model yang dibangun untuk menganalisis dan memahami faktorfaktor yang mempengaruhi diterimanya penggunaan teknologi komputer. Teori ini pertama kali dikemukakan oleh Davis (1986) dan selanjutnya dikembangkan oleh beberapa ilmuwan seperti Adams et al. (1992), Szajna (1994), Igbaria et al. (1995) serta Venkatesh \& Davis (2000).

Tujuan dari TAM yaitu menjelaskan dan memprediksikan penerimaan pemakai terhadap suatu teknologi. TAM yang dirumuskan oleh Davis (1989) adalah perceived usefulness, perceived ease to use, attitude, behavioural intention, and actual use. Selain itu ditambah dengan beberapa perspektif ekstenal yaitu job fit, experience and complexity. Berikut skema TAM menurut Davis dengan faktor-faktor yang saling berhubungan.

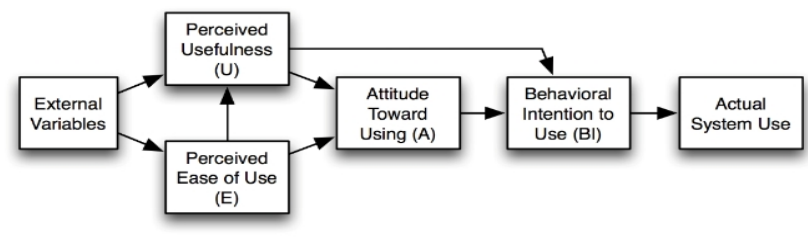

Gambar 1. Technology Acceptance Model menurut Davis

Kusmiati (2015) mengungkapkan sebuah institusi dikatakan sehat ketika pengelolaan yang terjadi transparan, akuntabel, birokratif namun tidak kaku, memegang standar baku mutu dan mempunyai kejelasan dalam target dan sasaran mutu yang ingin dicapai. Sehingga untuk mewujudkan akuntabilitas diperlukan sebuah organisasi yang menyuguhkan laporan keuangan secara transparan dan relevan, serta sistem penyaluran dana zakat secara baik.

Berbagai pihak yang terkait dalam penyaluran zakat seperti masyarakat dan negara menuntut agar BAZNAS dapat lebih akuntabel dan transparan dalam laporan penggunaan dana tersebut.

Wasila \& Shonhadji (2014) mengatakan akuntabilitas ditetapkan dalam organisasi meliputi aspek fisik, moral dan spiritual. Aspek fisik yang dimaksud adalah laporan keuangan, sedangkan aspek moral dan spiritual adalah akuntabilitas (pertanggungjawaban) kepada Allah dengan mencoba kegiatannya sesuai dengan shariah. Penelitian ini bertujuan untuk menganalisis penerimaan pengguna terhadap penerapan Sistem Informasi Manajemen Baznas (SIMBA) berdasarkan teori Technology Acceptance Model (TAM) serta menilai terkait pelaporan keuangan dalam SIMBA menghasilkan informasi yang akurat dan kesesuaian dengan PSAK Nomor 109.

\section{Metode}

\section{Jenis Penelitian}

Jenis penelitian ini menggunakan penelitian kualitatif dengan pendekatan studi kasus. Menurut Prasetyo (2016) penelitian kualitatif adalah penelitian yang menggunakan data dan alat analisis kualitatif, yaitu teori-teori yang difungsikan sebagai alat analisis.

\section{Sumber Data}

\section{Data Primer}

Dalam penelitian ini, data primer yang digunakan adalah opini atau pendapat oleh bagian administrasi, bagian informasi dan teknologi, dan bagian keuangan di BAZNAS Kabupaten Jember dari hasil wawancara yang dilakukan.

\section{Data Sekunder}

Data sekunder yang dikumpulkan berupa laporan keuangan dari BAZNAS Kabupaten Jember yang telah tersistem dalam SIMBA, yaitu neraca, laporan perubahan dana, laporan perubahan aset kelolaan, laporan arus kas dan catatan atas laporan keuangan pada tahun 2018.

\section{Lokasi Penelitian}

Lokasi penelitian ini adalah Badan Amil Zakat Nasional (BAZNAS) Kabupaten Jember di Jalan Nusantara H-8, Kaliwates, Jember.

\section{Teknik Analisis Data}

Dalam penelitian ini, awalnya peneliti mengumpulkan data yang diperlukan untuk dilakukan reduksi data dengan memfokuskan pada persepsi pengguna terhadap SIMBA dnegan berpedoman pada teori Technology Acceptance Model (TAM). Data yang diperoleh kemudian direduksi, data disajikan dalam bentuk uraian dan model gambar. Begitupula data sekunder yang telah direduksi juga akan dibandingkan dengan PSAK Nomor 109. Selanjutnya peneliti akan menarik kesimpulan. 


\section{Hasil dan Pembahasan}

\section{Hasil}

\section{Persepsi Pengguna Baznas Jember pada SIMBA}

\section{Persepsi Kegunaan Penggunaan (Perceived Usefulness)}

Endah sebagai operator yang tidak terlalu sering mengoperasikan SIMBA melihat dari sudut pandang kepercayaan bagi muzakki mengatakan dibawah ini:

"Yaiya bermanfaat. Jadi memang SIMBA itukan fungsinya agar baznas menjadi lembaga yang kredibel yang terpercaya, transparan juga, sehingga semua orang bisa lihat. Tapi ya gitu, ga seluruh satu-satu data, ya. Cuma penghimpunan, penyaluran gitu-gitu. Jadi SIMBA belum menyediakan misal apa kegiatannya di Baznas Jember, itu lebih ke website sih. Lebih meningkatkan kepercayaan dari muzakki, sehingga bisa menyebar ke yang lain."

Begitupun dengan Rania dan Rizandhi yang memiliki persepsi sama, yakni mendukung SIMBA sangat bermanfaat.

\section{Persepsi Kemudahan Penggunaan (Perceived Ease to Use)}

Rania mengatakan mudah menggunakan SIMBA, namun sesuai dengan jobnya sendiri dan untuk bagian lainnya belum pernah mengoperasikannya. Beliau mengatakan:

"Mudah, gak mudah kali ya, apa ya, ee.. kalau untuk yang baru dan bener-bener yang baru menurutku susah. Yang mudah dipahami itu hanya cara inputnya saja. Hanya input.. ya ada penyaluran itu. Ada pengumpulan, menerima uang, aku masukan ke SIMBA, melalui aktivitas, administrasi, muzakki, disini ada muzakki perseorangan dan lembaga. Muzakki lembaga kita langsung bayar zis. Ini yang udah terdaftar, jadi yang belum terdaftar kita registrasi dulu. Jadi sebenernya SIMBA ini lengkap, tapi belum aku pelajari gimana-gimana."

Endah dan Rizandhi juga memiliki persepsi sama, dimana SIIMBA mudah digunakan sesuai dengan sistem yang ada.

\section{Sikap Terhadap Pengaplikasian (Attitude Toward Using)}

Beberapa operator yang ditunjuk oleh Baznas Jember memiliki sikap yang pro terhadap penggunaan SIMBA. Seperti yang dikemukakan oleh Endah:

"Dukung, kita kan juga susah ya record sendiri. Muzakki itu kan banyak toh, mau kirim sms satu-satu itu susah. Khusus untuk eksternal aja, bukan internal. Cukup terbantu dengan SIMBA.”

\section{Perilaku Keinginan untuk Menggunakan (Behavioral Intention to Use)}

Endah, Rania dan Rizandhi mengatakan demikian, bahwa SIMBA didukung penuh oleh Baznas Jember karena penggunaannya yang efektif dan efisien. Salah satu kutipan dari Endah:

"Mendukung. Kan yang tadi aku bilang SIMBA memudahkan untuk me-record data muzakki dan mustahik."

\section{Pemakaian Sebenarnya (Actual Use)}

Endah mengemukakan bahwa tidak butuh menunggu waktu lama jika meng-input data, namun untuk menghasilkan laporan keuangan kurang memahami dalam hal itu. Rania juga mengatakan apabila ada muzakki atau perwakilan UPZ meminta SK maka langsung melakukan peng-input-an data.

"Langsung diinput. Dananya berupa kas atau nonkas. Sudah lengkap pilihannya di SIMBA. Jadi yang bener tak pahami ya ini."

\section{Kesesuaian Tugas (Job Fit)}

Baznas Jember memiliki strukur organisasi yang memiliki tugas masing-masing dan melalui SIMBA ini masing-masing dapat mengakses namun sesuai dengan job sendiri. Rizandhi mengatakan:

"Tidak melulu orang itu aja kok, pekerja Baznas ada job masing-masing di SIMBA."

\section{Pengalaman (Experience)}

Endah menjelaskan bahwa penting diadakannya pelatihan terhadap yang berpengalaman atau tidak, berikut penyataannya:

"Iya. Memang ada namanya bimtek, bimbingan teknis. Nah aku ini belum pernah dibolehin ikut ini. Sebelumnya ada bimtek 1, mas Arif yang datang. Ada kemarin pelatihan SIMBA, tapi tidak ada yang mau memberangkatkan. Gak tau kenapa. Senin selasa minggu ini. Di Surabaya."

Rizandhi mengatakan bahwa tidak hanya orang yang berpengalaman dapat mengaplikasikan SIMBA, namun yang tidak berpengalaman dapat melakukan pelatihan.

"Tidak hanya yang berpengalaman juga, bisa diadakan training Baznas Jember mendatangkan dari Baznas Provinsi Jawa Timur yang sudah berpengalaman. Sehingga ditraining cara-cara peng-input-annya."

\section{Kerumitan (Complexity)}

Kerumitan yang terjadi dalam SIMBA dilihat dari menu opsi yang ada di dalamnya. Rizandhi mengatakan pada awalnya pernah mengalami kerumitan, namun dengan diadakannya pelatihan maka dapat tersolusikan. Beliau mengatakan:

"Namanya juga gak tau kan ya, awal kan gak tau, training itu agak sulit mempelajarinya, tentornya itu kasih tau caracaranya. Kita melakukan pengiputan, caranya muzakki menyetor, pendistribusian, kas masuk kas keluar. Itu kerumitan-kerumitan awal, dan lama-lama ya bisa lah, kalau gak ditraining ya kan bingung toh."

\section{Pelaporan Keuangan dalam SIMBA}

Pemerintah berinisiatif membentuk SIMBA yang telah disesuaikan dengan PSAK 109 sangat memudahkan BAZNAS dalam pembuatan laporan keuangan. Laporan keuangan yang telah diatur oleh PSAK 109 terdiri dari 5 macam, begitupun yang ada di dalam SIMBA bahwa sistem tersebut juga dapat menghasilkan 5 laporan keuangan. Seperti yang dikemukan oleh Rizandhi:

“Ada semuanya lengkap. CALK juga ada, lengkap kok. Jadi kalau CALK itu ngisi sendiri, tapi ini kayaknya belum diisi. Tapi ini ada yang belum diisi, makanya ini ada yang belum valid."

Di dalam SIMBA memungkinkan tidak ditemukan akun yang sesuai dengan kebutuhan Baznas, maka dimudahkan pengaturan untuk bisa menambah akun baru. Pilihan menu ini terdapat di sebelah menu laporan, sehingga pengguna harus 
mengetahui terlebih dulu akun ini termasuk kelompok apa, misalnya aset atau liabilitas atau ekuitas. Rizandhi mengatakan:

"Bisa nambah akun baru. Pernah waktu itu ada akun nambah sendiri tentang.. pasar murah, ya kayak sembako murah lah. Jadi ada setting jenis akun, akun level 1, 2, 3, 4, dan 5. Jadi level ini untuk penggolongan akun itu, mulai dari level 1 itu masuk aset, kewajiban atau ekuitas. Kalau sudah isi level 1 baru bisa isi level 2, gitu seterusnya. Tapi aku gak berani nambahin ini. Gak bisa dihapus kayae."

SIMBA yang masih diresmikan sekitar tahun 2016 masih memungkinkan adanya masalah dari output yang dihasilkan. Ketidaksesuain input dan output yang masih membuat informasi tidak akurat. Rizandhi mengatakan:

"Kadang kita pernah trouble diSIMBA, kita laporan ke provinsi. Di laporannya itu ada amil sekian, padahal di menunya kita gak masukin amil. Itu pernah rancu kemarin. Berapa ratus juta gitu, kita gak ambil sekian padahal. Waktu itu provinsi bilangnya gak sempurna, tahun 2018 pertengahan itu masih belum perfect. Trus aku mikir-mikir ya sampe sekarang kadang yo ada yang gak sempurna kadang nganu. Jadi kita ga ngilangin dana amil wes. Katanya biarin dulu. Katanya provinsi belum perfect, pusat bilang ya iya ke provinsi emang belum perfect lah istilahnya. Ya sementara emang ga ngilangin."

\section{Pembahasan}

\section{Persepsi Pengguna Terhadap SIMBA menurut teori} TAM

Dari hasil lapang, pengguna SIMBA menerima penerapan SIMBA dipengaruhi oleh semua faktor yang telah dibentuk oleh Davis (1989). Peneliti menduga faktor penerimaan teknologi bagi pengguna dapat dipengaruhi oleh sumber daya manusia. Salah satu keberhasilan suatu organisasi mencapai tujuan sangat ditentukan oleh kemampuan dan keterampilan sumber daya manusianya, yang dimaksud adalah pegawai. Pentingnya kualitas sumber daya manusia dalam perusahaan menjadikan kompetensi sebagai salah satu aspek penentu keberhasilan (Jufri, 2018). Tanpa kompetensi, pekerjaan tidak akan dapat diselesaikan secara baik. Baznas Jember masih memiliki kualitas sumber daya manusia yang kurang, dimana lebih spesifik permasalahannya dalam kompetensi. Adapun Rania menyampaikan bahwa pemanfaatan SIMBA kurang maksimal karena faktor sumber daya manusia di Baznas Jember.

"Adanya SIMBA kan belum maksimal, faktor dari sdm juga. Kaya ada penyaluran dari lembaga, ada beberapa yang terlewat dari SIMBA. Pemanfaatan SIMBA belum maksimal disini."

Definisi kompetensi menurut Hutapea \& Nurianna (2008:4) kompetensi adalah kapasitas yang ada pada seseorang yang bisa membuat orang tersebut mampu memenuhi apa yang disyaratkan oleh pekerjaan dalam suatu organisasi sehingga organisasi tersebut mampu mencapai hasil yang diharapkan. Dalam kasus Baznas Jember bahwa kompetensi sangat mempengaruhi bagaimana kompetensi sumber daya manusia dapat mengoptimalkan fungsi SIMBA sehinga dapat dimanfaatkan semestinya. Menurut Hutapea \& Nurianna (2008:8) mengungkapkan ada tiga komponen utama pembentukan kompetensi antara lain pengetahuan (knowledge), keterampilan (skill) dan sikap (attitude).

\section{Pengetahuan (knowledge)}

Pengetahuan diartikan sebagai informasi yang dimiliki oleh seorang pegawai untuk melaksanakan tugas dan tanggungjawab sesuai bidang yang digelutinya. Pegawai Baznas Jember dalam mengoperasikan SIMBA harus memiliki pengetahuan tentang SIMBA itu sendiri, manfaatnya, khusus untuk bagian keuangan dan pelaporan harus memiliki pengetahuan tentang akuntansi dimana hubungannya dengan pengakuan, penyajian dan pengungkapan, selain itu juga harus memiliki pengetahuan tentang komputer dan sistem informasi agar tidak ada kesulitan dalam pengoperasiannya. Bidang keuangan dan pelaporan minimal diposisikan oleh seseorang lulusan sarjana ekonomi jurusan akuntansi.

\section{Keterampilan (skill)}

Keterampilan merupakan kemampuan yang dimiliki seseorang dalam mengerjakan dan menyelesaikan sebuah pekerjaan. Keterampilan sangat dibutuhkan dlaam organisasi, misalnya keterampilan berkomunikasi dan menggunakan teknologi informasi. Hasil penelitian di Baznas Jember bahwa pada umumnya para pegawai khususnya pengguna SIMBA telah memiliki keterampilan seperti menggunakan teknologi komputer sebab pada bidang tersebut tidak dibutuhkan keterampilan khusus.

Berbeda dengan bidang keuangan dan pelaporan bahwa SIMBA telah menyediakan informasi terkait operasional Baznas dalam satu periode dimana pengguna perlu keterampilan khusus dan diberi pelatihan sebelum menempati posisi tersebut. SIMBA secara keseluruhan baik informasi manajemen maupun informasi pelaporan untuk pengguna awal terlihat rumit dan sulit sehingga hanya dapat dioperasikan oleh pengguna yang memiliki keterampilan khusus. Sebagai bidang keuangan dan pelaporan tentu dibutuhkan keterampilan akuntansi dalam pengoperasiannya, misalnya bagaimana aset kas ataupun non kas diakui, penyusutan aset, pengungkapan pada Catatan Atas Laporan Keuangan, dan lainnya. Pengguna dituntut mempunyai ideide untuk pemenuhan informasi keuangan tersebut. Minimal pegawai mengikuti pelatihan penggunaan SIMBA yang telah dilaksanakan oleh tim SIMBA. Baznas Jember telah diundang untuk megikuti bimtek (bimbingan teknis) SIMBA dua kali yaitu tahun 2018 dan 2019. Pelatihan tersebut belum pernah dihadiri oleh Rania atau Rizandhi sehingga keduanya belum memiliki keterampilan dalam penggunaan SIMBA. Berikut pernyataan Rania bahwa pada bidang tersebut bukan posisi yang mudah.

"Kalau mau cari, ini posisine bukan receh, ini akuntan loh, ini yang bener dari akuntansi, paham dengan pembukuan."

\section{Sikap (attitude)}

Sikap merupakan pola tingkah seseorang pegawai di dalam peran melaksnakan tugas dan tanggungjawab sesuai dengan peraturan perusahaan. Poin ini tidak perlu dibahas oleh peneliti karena telah masuk dalam model penerimaan teknologi yang diungkapkan oleh Davis. Peneliti menduga model penerimaan teknologi dengan dua faktor tambahan yaitu pengetahuan (knowledge) dan keterampilan (skill). 


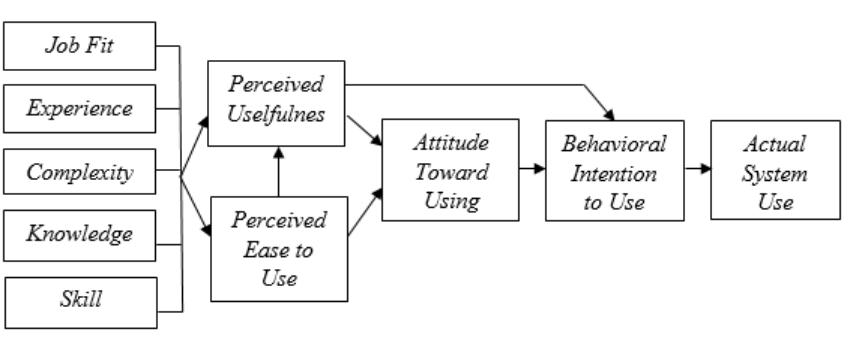

Gambar 2. Model dugaan teori TAM berdasarkan hasil penelitian

\section{Pelaporan Keuangan SIMBA Sesuai dengan PSAK 109}

\section{Pengakuan dan pengukuran}

PSAK 109 telah mengatur ketika ada dana zakat, infak/sedekah yang masuk di Baznas, dimana diakui sebagai kas atau nonkas beserta besar jumlahnya. SIMBA telah menyediakan pilihan untuk pengakuan dan pengukuran tersebut. Bagian input data dengan mudah dapat memilih aset yang diterima berupa kas atau nonkas. Pengguna telah mengakui aset nonkas sesuai dengan PSAK 109, dimana perhitungannya sesuai dengan harga pasar.

\section{Penyajian}

PSAK 109 mengatur bahwa penyajian dana zakat, dan infak/sedekah, dan dana amil terpisah pada laporan posisi keuangan. SIMBA sendiri secara otomatis menghasilkan laporan keuangan, salah satunya adalah laporan posisi keuangan. Baznas Jember sendiri masih belum menyempurnakan datanya di dalam SIMBA, sehingga masih terlihat kurang lengkap. Misalnya di akun aset tidak lancar, masih belum ada nilainya dan juga liabilitas yang masih belum ada nilainya.

\section{Pengungkapan}

PSAK 109 mengatur apa saja yang harus diungkap oleh Baznas dalam bentuk catatan atas laporan keuangan. Pengungkapan di SIMBA masih tergolong manual, dimana hanya menyediakan textbox untuk diisi sesuai kebijakan masing-masing. Kekurangan dari SIMBA sendiri masih belum bisa mengunduh catatan atas laporan keuangan milik Baznas Jember. Sesuai dengan survei lapang bahwa sistem akan merespon apabila pengungkapan tersebut belum benar, dari segi isi pengungkapan tersebut yang tidak sesuai dengan PSAK 109 atau kurangnya kelengkapan data.

\section{Simpulan}

\section{Simpulan}

1. Penerimaan pengguna terhadap SIMBA, yaitu bagian administrasi, bagian IT dan bagian keuangan sesuai dengan faktor yang saling mempengaruhi faktor utama pada teori TAM (Technology Acceptance Model) yaitu perceived usefulness (persepsi kegunaan penggunaan) dan perceived ease to use (persepsi kemudahan pemakaian). Berdasarkan hasil analisis, peneliti menduga bahwa ada faktor eksternal lain yang mempengaruhi pengguna menerima teknologi, antara lain pengetahuan (knowledge) dan keterampilan (skill).

2. Laporan keuangan di SIMBA telah sesuai dengan PSAK 109 namun belum mencerminkan informasi yang akurat. Baznas Jember saat ini masih belum mengambil hak amil sesuai dengan kesepakatan pimpinan dan pekerja, namun laporan yang dihasilkan oleh SIMBA jumlah pengumpulan zakat secara otomatis terpotong dengan hak amil sebesar $12,5 \%$. Hal ini dikarenakan tidak mengubah jumlah hak saat RKAT di awal tahun 2018. Catatan atas laporan keuangan belum bisa diunduh di menu SIMBA dan Baznas Jember masih belum mengisinya sesuai aturan di PSAK 109.

\section{Keterbatasan}

1. Baznas Jember belum menentukan bagian hak amil sehingga tidak dapat memberikan informasi yang relevan dengan laporan keuangan yang dihasilkan oleh SIMBA,

2. Sumber daya manusia di Baznas Jember sangat terbatas yang memiliki pengetahuan dan keterampilan dalam penggunaan SIMBA sehingga peneliti hanya mengetahui secara umum tentang SIMBA,

3. Pihak manajemen Baznas Jember belum mengizinkan terkait isi dalam laporan keuangan sehingga peneliti hanya dapat menganalisis format laporan keuangan tanpa jumlah nominalnya.

Kurangnya pengetahuan dari peneliti tentang perkembangan teori Technology Acceptance Model, dimana masih menggunakan teori yang dirumuskan oleh Davis (1989).

\section{Referensi}

Adams, D. A., Nelson, R. R., Todd, P. A., Adams, B. D. A., Nelson, R. R., \& Todd, P. A. (1992). Perceived Usefulness, Ease of Use, and Usage of Information Technology: A Replication. 16(2), 227-247. https://doi.org/10.2307/249577

Davis, F. D. (1986). A Technology of Acceptance Model for Empirically Testing New-End User Information System: Theory and Result [Massachusetts Institute of http://hdl.handle.net/1721.1/15192

Davis, F. D. (1989). Perceived Usefulness, Perceived Ease of Use, and User Acceptance of Information Technology. MIS Quarterly, 13(0), 319340. https://doi.org/10.1016/j.cell.2017.08.036

Hutapea, P., \& Nurianna, T. (2008). Kompetensi Komunikasi Plus: Teori, Desain, Kasus dan Penerapan untuk HR dan Organisasi yang Dinamis. Jakarta: Gramedia Pustaka Utama.

Igbaria, M., Guimaraes, T., \& Davis, G. B. (1995). Testing the Determinants of Microcomputer Usage via a Structural Equation Model. Journal of Management Information Systems ISSN:, 11(4), 87-114. https://doi.org/10.1080/07421222.1995.11518061

Jufri, Z. K. (2018). Kompetensi Sumber Daya Manusia Di Kantor Sistem Administrasi Manunggal Satu Atap ( Samsat ) Wilayah. Jurnal Administrasi Negara, 5(2), 1-9.

Kusmiati, M. (2015). Membangun Kesehatan Organisasi Institusi Pendidikan Dokter: sebuah Transformasi menuju Akuntabilitas Sosial. MIMBAR, Jurnal Sosial Dan Pembangunan, 31(1), 123-134. https://doi.org/10.29313/mimbar.v31i1.1266

Permudah Transaksi, BAZNAS Luncurkan Sistem Manajemen Berbasis Teknologi | gomuslim. (n.d.). Retrieved March 14, 2020, from https://www.gomuslim.co.id/read/news/2016/10/05/1690/permudahtransaksi-baznas-luncurkan-sistem-manajemen-berbasisteknologi.html

Prasetyo, W. (2016). Penelitian Kualitatif Untuk “Mewarnai” Disiplin Akuntansi.

Szajna, B. (1994). Software Evaluation and Choice: Predictive Validation of the Technology Acceptance Instrument. MIS Quarterly: Management Information Systems, 18(3), 319-324. https://doi.org/10.2307/249621

Triyuwono, I. (2001). Metafora Zakat Dan Shari'Ah Enterprise Theory Sebagai Konsep Dasar Dalam Membentuk Akuntansi Syari'Ah. Jurnal Akuntansi Dan Auditing Indonesia, 5(2), 131-145.

Undang-Undang Republik Indonesia Nomor 23 Tahun 2011. Pengelolaan Zakat. 24 November 2011. Lembaran Negara Republik Indonesia Tahun 2011 Nomor 115. Jakarta. (n.d.).

Venkatesh, V., \& Davis, F. D. (2000). A Theoretical Extension of the Technology Acceptance Model: Four Longitudinal Field Studies. Management Science, 46(2), 186-204. https://doi.org/10.1287/mnsc.46.2.186.11926 
Wasila, S., \& Shonhadji, N. (2014). A Study on the Zakat and Infaq or Sodaqoh Accounting Application under SFAS 109 in Al-Falah Soscial Fund Foundation (YSDF) Surabaya. The Indonesian Accounting
Review, 4(02), 169. https://doi.org/10.14414/tiar.v4i02.332. 